\title{
KEWAJARAN NILAI PASAR SAHAM PERUSAHAAN PASCA RIGHT ISSUE
}

\author{
Rifki Khoirudin ${ }^{1,}$ Desta Rizky Kusuma ${ }^{2}$ \\ ${ }^{1,2}$ Fakultas Ekonomi Universitas Ahmad Dahlan Yogyakarta \\ Email: rifki.khoirudin@ep.uad.ac.id
}

\begin{abstract}
This study aims to estimate the fair value per share of PT BW Plantation Tbk after the company offered right issue. This study is also intended to find out the fair market value per share of PT BW Plantation Tbk post-rights issue. The information used in this study was obtained from secondary data from the financial statements of PT BW Plantation Tbk., which were audited by public accountants and other information available in the financial statements. BW Plantation Tbk., The company's financial statements comparison, and the company's stock price data comparison.The methods of analysis used in determining the fair value per share is the Discounted Cash Flow and Relative Valuation. Discounted Cash Flow analysis was done by: projections of financial statements i.e. balance sheet and income statement, the projected Free Cash Flow to Equity (FCFE), the determination of the discount rate, the determination of Terminal Value, and the estimated fair value of equity. Analysis of Relative Valuation begins with finding the comparison companies in the same business line, select and assign the appropriate multiple of the comparison companies. Multiple used are: Price Earnings Ratio (PER), Price to Book Value (PBV), and Price to Sales Ratio (P/S).
\end{abstract}

Keywords: valuation of shares, rights issue, discounted cash flow, relative valuation JEL Classification: E44, G12

\section{PENDAHULUAN}

Pada umumnya setiap perusahaan mempunyai keinginan untuk memperluas usahanya, hal ini dilakukan dengan mengadakan ekspansi. Untuk melakukan ekspansi ini perusahaan memerlukan tambahan mo-dal cukup besar. Dalam rangka memenuhi kebutuhan dana yang cukup besar tersebut, sering kali dana yang diambil dari dalam perusahaan tidak cukup. Untuk itu diper-lukan usaha mencari sumber dana dari luar perusahaan, yaitu di pasar modal, dengan cara melakukan emisi saham.

Secara sederhana, pasar modal merupakan tempat untuk menerbitkan atau memperdagangkan surat-surat berharga jangka panjang, khususnya saham dan obli-gasi. Alasan perusahaan memutuskan untuk menerbitkan saham di pasar modal adalah untuk melakukan perluasan usaha tetapi perusahaan tidak ingin menambah utang atau untuk mengganti sebagian utang de-ngan ekuitas yang diperoleh dari penerbitan saham (Husnan, 2001).
Melalui pasar modal, suatu perusahaan dapat menjual sahamnya kepada pu-blik guna memperoleh sumber dana untuk kegiatan ekspansi atau operasi perusahaan. Melalui pasar modal pula, para investor da-pat menanamkan modalnya (berinvestasi) dengan membeli sejumlah efek dengan ha-rapan akan memperoleh keuntungan dari hasil kegiatan tersebut. Investasi dapat diartikan sebagai suatu kegiatan menempatkan dana pada satu aset atau lebih selama periode tertentu dengan harapan akan memperoleh keuntungan. Namun dalam beberapa waktu terakhir pasar modal Indonesia telah menunjukkan perkembangan yang cukup menggairahkan, menjadikan semakin banyaknya saham yang terdaftar di Bursa Efek, hal ini tentunya memerlukan strategi tertentu untuk membeli saham yang kiranya akan menguntungkan, di mana saham-saham yang dijual pada pasar perdana dapat menjadi pilihan untuk berinvestasi. Kegiatan perusahaan untuk menjual saham-nya kepada publik melalui pasar 
modal salah satunya dapat dilakukan dengan cara Right Issue.

Sedangkan menurut Husnan (2001) kelebihan right issue adalah:

1) Biaya lebih murah dibandingkan penawaran umum karena perusahaan tidak diharuskan menggunakan penjamin (underwriter) yang akan menjamin bahwa saham yang ditawarkan laku semua.

2) Pemegang saham lama dapat mempertahankan proporsi kepemilikan sa-hamnya.

3) Pemegang saham lama diprioritaskan dalam pembelian saham baru.

4) Saham bisa menjadi lebih likuid karena jumlahnya menjadi jauh lebih besar dan bisa meningkatkan frekuensi perdagangan.

Dalam penelitian ini peneliti menggunakan obyek penelitian yaitu PT. BW Plantation Tbk yaitu perusahaan go public yang bergerak di bidang industri perkebunan kelapa sawit. Industri perkebunan kelapa sawit diprediksi di masa mendatang mempunyai prospek yang baik. Hal ini didasari antara lain dengan adanya permintaan di dalam negeri yang searah dengan kebijakan pemerintah untuk mengembangkan bahan bakar nabati (BBN) sebagai alternatif bahan bakar minyak (BBM) memberi peluang besar bagi industri kepala sawit untuk lebih berkembang.

Pertumbuhan penggunaan minyak kelapa sawit juga didukung oleh pertambahan penduduk dunia dan semakin berkembangnya penggunaan minyak kelapa sawit dalam berbagai kegiatan industri lain-nya. Di antaranya dalam industri makanan untuk bahan dasar oleochemical, industri kosmetik dan lainnya. Industri kelapa sawit mempunyai rantai bisnis yang cukup pan-jang dan saling terkait. Mulai dari pe-nyiapan lahan, pembibitan, supporting industri, pengolahan di industri hulu sampai pada industri hilir. Kebijakan pengembang-an sektor ini benar-benar harus melalui koordinasi yang kuat antar instansi terkait sehingga bisa mencapai hasil yang optimal bagi pembangunan ekonomi nasional. Dengan ketersediaan lahan dan iklim yang mendukung, sektor ini berpeluang untuk memberikan andil yang cukup besar dalam pertumbuhan ekonomi Indonesia.

PT. BW Plantation Tbk sendiri didi-rikan pada tanggal 6 November 2000 de-ngan nama PT. Bumi Perdana Prima Inter-national. Perusahaan mengubah namanya menjadi PT. BW Planatation Tbk pada ta-hun 2007. Kegiatan bisnis utama Peru-sahaan adalah mengembangkan, membudi-dayakan, dan memanen Tandan Buah Segar (TBS), serta mengekstraksi Crude Palm Oil (CPO) dan inti sawit atau Palm Kernel (PK). Dalam kegiatan operasionalnya, Pe-rusahaan memiliki 3 (tiga) pabrik kelapa sawit (PKS) dengan total kapasitas pro-duksi 150 ton per jam yang ditunjang se-penuhnya oleh infrastruktur perkebunan dan pengolahan kelapa sawit. (Laporan tahunan PT. BW Plantation Tbk 2013)

Sedangkan dalam Rapat Umum Pemegang Saham Luar Biasa (RUPSLB) PT. BW Plantation Tbk, yang dilaksanakan pada tanggal 27 November 2014 memutus-kan antara lain (www.britama.com):

1) Menyetujui peningkatan modal dasar yang semula berjumlah $\mathrm{Rp}$ 900.000.000.000, yang terbagi atas 9.000.000.000 saham dengan nilai nominal saham $\mathrm{Rp} 100$, menjadi berjumlah $\mathrm{Rp}$ 5.000.000.000.000, yang terbagi atas 50.000.000.000 saham dengan nilai nominal saham $\mathrm{Rp}$ 100 ,

2) Menyetujui rencana untuk melakukan Penawaran Umum Terbatas I (PUT I) dengan Hak Memesan Efek Terlebih Dahulu (HMETD) untuk 27.021.678.000 saham biasa dengan nilai nominal Rp100, dan setiap 1 pe-megangan saham berhak 6 HMETD dengan harga pelaksanaan Rp400,

3) Menyetujui rencana akuisisi seluruh saham Green Eagle Holding Pte Ltd. 
Adapun rencana penggunaan dana yang di peroleh dari hasil Right Issue setelah dikurangi biaya-biaya emisi akan digunakan untuk pendanaan akuisisi Grup Green Eagle sebesar Rp10.530 miliar dan sisanya akan digunakan untuk pendanaan modal kerja BWPT dan anak usahanya, yaitu PT Sawit Sukses Sejahtera (SSS), PT Wana Catur Jaya Utama (WJU) dan PT Satria Manunggal Sejahtera (SMS) dengan alokasi penggunaan dana pada tahun 2014 dan 2015. Adapun alokasi penggunaan dana di SSS, WJU dan SMS pada awalnya akan dicatat sebagai inter-company loan yang akan dikonversi menjadi peningkatkan modal Perseroan yang akan di realisasikan selambat-lambatnya pada tahun 2015 (www.britama.com).

Berdasarkan latar belakang yang dijelaskan sebelumnya, pertanyaan penelitian dapat disimpulkan sebagai berikut: (1) Bagaimana mengestimasi nilai saham yang wajar dari perusahaan PT. BW Plantation, Tbk pasca melakukan right issue? dan, (2) Bagaimana nilai pasar yang wajar saham perusahaan PT. BW Plantation, Tbk pasca melakukan right issue?

\section{TINJAUAN PUSTAKA DAN HI- POTESIS \\ Pengertian Nilai}

Standar Penilaian Indonesia dalam Konsep dan Prinsip Umum Penilaian /KP-UP (2013: 4.4) menyatakan bahwa nilai adalah suatu opini dari manfaat ekonomi atas kepemilikan aset, atau harga yang pa-ling mungkin dibayarkan untuk suatu aset dalam pertukaran, sehingga nilai bukan merupakan fakta. Aset diartikan juga sebagai barang dan jasa.

Pengertian tentang nilai yang dikemukakan oleh (Hidayati dan Harjanto 2003) bahwa sesuatu barang/benda akan mempunyai nilai bagi seseorang jika barang/benda tersebut memberikan makna atau arti bagi seseorang tersebut. Nilai merupakan perkiraan manfaat ekonomi atas barang dan jasa pada suatu waktu tertentu atau apa yang sepatutnya dibayar oleh seorang pembeli atau diterima oleh penjual dalam sebuah transaksi.

Sementara (Rezaee: 2001) menya-takan bahwa nilai tidak statis atau sebuah konsep yang homogen. Nilai dari sebuah aset tergantung pada banyak faktor yang dapat berubah setiap saat. Faktorfaktor tersebut antara lain adalah lingkungan eko-nomi secara keseluruhan, penggunaan po-tensial dari aset, waktu estimasi nilai, lo-kasi, kelangkaan dari nilai aset substitusi, kepemilikan likuiditas dan pasar dari aset, serta kondisi aset tertentu.

Dari ketiga konsep di atas dapat disimpulkan bahwa nilai merupakan panda-ngan pasar pada umumnya atas manfaat ekonomi yang dapat diperoleh dari suatu barang/benda atau jasa yang dapat di-transaksikan antara penjual dan pembeli.

Nilai Pasar

Nilai pasar didefinisikan sebagai es-timasi sejumlah uang yang dapat diperoleh dari hasil penukaran suatu aset atau lia-bilitas pada tanggal penilaian, antara pem-beli yang berminat membeli dengan penjual yang berminat menjual, dalam suatu tran-saksi bebas ikatan, yang pemasarannya di-lakukan secara layak, di mana kedua pihak masing-masing bertindak atas dasar pema-haman yang dimilikinya kehati-hatian dan tanpa paksaan (SPI, 2013).

Istilah nilai pasar yang terdapat dalam SPI dan nilai wajar yang biasa digunakan dalam standar akuntansi. Dalam hal tidak tersedianya data berbasis pasar, Nilai Wajar dapat menggunakan Nilai Pasar untuk Penggunaan Yang Ada atau Nilai dalam Penggunaan. Nilai wajar dalam konsep ak-untansi, didefinisikan dalam International Financial Reporting Standards (IFRS) dan PSAK (Pedoman Standar Akuntansi Keua-ngan) sebagai jumlah untuk suatu aktiva yang dapat ditukar, atau penyelesaian ke-wajiban, antara pihak yang memahami dan 
berkeinginan untuk melakukan transaksi bebas ikatan (arm's length transaction). Ni-lai wajar pada umumnya digunakan untuk pelaporan baik nilai pasar maupun selain nilai pasar dalam laporan keuangan. (SPI,2013).

Nilai pasar wajar yang digunakan khusus dalam penilaian bisnis memiliki pe-ngertian yang sama dengan nilai pasar. Ni-lai pasar wajar tidak seharusnya dirancukan dengan nilai wajar dalam akuntansi.

Dari definisi di atas dapat disimpul-kan bahwa nilai pasar adalah harga dari suatu transaksi yang memenuhi unsur-un-sur yaitu pembeli dan penjual berkehendak melakukan transaksi, dalam keadaan pasar terbuka, penjual dan pembeli mempunyai pengetahuan dan informasi yang mencu-kupi mengenal obyek yang ditransaksikan, jangka waktu penawaran mencukupi, dan pembeli/penjual istimewa diabaikan (Hidayati dan Harjanto, 2003).

Penentuan nilai wajar suatu perusahaan dilakukan untuk mengetahui kondisi nilai perusahaan. Penilaian tersebut diguna-kan dalam rangka proses akuisisi, merger atau untuk mengetahui overvalued atau undervalued harga saham perusahaan yang terjadi dipasar efek. (Pratt dan Niculita 2008) mendefinisikan nilai wajar sebagai harga yang akan diterima untuk menjual a-set atau yang akan dibayar untuk mentra-nsfer kewajiban transaksi secara tertib anta-ra peserta pasar pada suatu tanggal tertentu.

\section{Nilai Intrinsik}

Nilai intrinsik atau nilai teoritis ada-lah nilai sebuah aktiva menurut perhitungan investor tertentu yang ditentukan oleh fakta. Nilai intrinsik dari saham adalah nilai saham berdasarkan estimasi investor terten-tu terhadap aliran deviden saham, sehingga dengan demikian nilai intrinsik dapat ber-beda-beda diantara para investor tergantung pada seberapa optimistik mereka terhadap perusahaan (Brigham dan Houston 2001).
Prawoto (2004) mendefinisikan nilai intrinsik adalah jumlah yang dipertimbangkan oleh investor berdasarkan evaluasi atas fakta-fakta yang ada, yang merupakan nilai riil dari suatu artikel tertentu biasanya berupa ekuitas. Damodaran (2002) mende-finisikan nilai intrinsik sebagai nilai dari perusahaan yang diestimasi oleh analis di mana tidak hanya aliran kas yang diharap-kan saja yang diestimasi tetapi juga menges-timasi tingkat diskon atas aliran kas tersebut dengan tingkat ketepatan yang tinggi.

Menurut (Tandelilin 2010) di dalam penilaian saham dikenal adanya tiga nilai yaitu: nilai buku, nilai pasar, dan nilai in-trinsik. Nilai buku merupakan nilai yang dihitung berdasarkan pembukuan perusa-haan penerbit saham (emiten). Nilai pasar adalah nilai saham di pasar, yang ditun-jukkan oleh harga saham tersebut di pasar. Nilai intrinsik atau dikenal dengan nilai teo-ritis adalah nilai saham yang sebenarnya a-tau seharusnya terjadi.

Dalam penilaian usaha, menghitung nilai intrinsik dan mengetahui nilai pasar dari saham dapat berguna untuk menge-tahui apakah saham tersebut termasuk sa-ham yang dijual dengan harga murah (un-dervalued) atau saham tersebut dijual de-ngan harga mahal (overvalued). Nilai pasar yang lebih kecil dari nilai intrinsiknya me-nunjukkan bahwa saham tersebut dijual de-ngan harga yang murah (undervalued), ka-renanya investor membayar saham tersebut lebih kecil dari yang seharusnya dia bayar. Sebaliknya nilai pasar yang lebih besar dari nilai intrinsik menunjukkan bahwa saham tersebut dijual dengan harga yang mahal/overvalued (Jogiyanto, 2009).

Investor berkepentingan untuk mengetahui ketiga nilai tersebut sebagai informasi penting dalam pengambilan keputusan investasi yang tepat. Dalam membeli atau menjual saham, investor akan membandingkan nilai intrinsik dengan nilai pasar saham bersangkutan. Jika nilai pasar suatu saham lebih tinggi dari nilai intrin-siknya, berarti saham 
tersebut tergolong mahal (overvalued). Dalam situasi seperti ini, investor tersebut bisa mengambil kepu-tusan untuk menjual saham tersebut. Seba-liknya jika nilai pasar suatu saham lebih rendah dari nilai intrinsiknya, berarti saham tersebut tergolong murah (undervalued), sehingga dalam situasi seperti ini investor sebaiknya membeli saham tersebut.

Husnan (2003) berpendapat analisis saham bertujuan untuk menaksir nilai intrinsik suatu saham, dan kemudian mem-bandingkannya dengan harga pasar saat ini (current market price) saham tersebut. Ni-lai intrinsik menunjukkan present value a-rus kas yang diharapkan dari saham terse-but. Pedoman yang digunakan adalah seba-gai berikut.

1) apabila nilai intrinsik > harga pasar saat ini, maka saham tersebut dinilai undervalued (terlalu rendah);

2) apabila nilai intrinsik < harga pasar saat ini, maka saham tersebut dinilai overvalued (terlalu tinggi);

3) apabila nilai intrinsik = harga pasar saat ini, harga saham itu dinilai wajar;

Dapat disimpulkan bahwa nilai intrinsik saham adalah sebagai nilai dari sebuah saham ketika faktor utama yang mem-pengaruhi nilai dipertimbangkan, dengan kata lain nilai intrinsik atau nilai teoritis merupakan nilai sebenarnya atau nilai yang seharusnya terjadi dari selembar saham. Konsep nilai intrinsik tidak dapat dipi-sahkan dari konsep nilai pasar yang wajar karena tindakan yang dilakukan oleh pembeli dan penjual didasarkan oleh persepsi mereka tentang nilai intrinsik yang akhirnya akan mengarah pada kesepakatan tentang nilai wajar.

\section{Pengertian Saham}

Menurut Riyanto (1996) saham adalah tanda bukti pengambilan bagian atau peserta dalam suatu perseroan terbatas, yang pada umumnya terdiri dari tiga jenis yaitu saham biasa (common stock), saham preferen (preffered stock) dan saham kumulatif preferen (cumulative preferred stock). Menurut Husnan (2003), pemilik saham suatu perusahaan disebut juga pemegang saham, merupakan pemilik peru-sahaan. Tanggung jawab pemilik perusa-haan yang berbentuk PT terbatas pada modal yang disetorkan. Sementara Tande-lilin (2010) membagi saham ke dalam em-pat kelompok yaitu saham biasa, saham preferen, bukti right dan waran.

Sekuritas yang diperdagangkan di pasar bersifat ekuitas Indonesia adalah saham baik saham biasa maupun saham preferen serta bukti right dan waran. Dari keempat sekuritas ekuitas ini, saham biasa merupakan sekuritas yang terpenting dan paling dikenal oleh masyarakat Indonesia. Oleh karenanya, sebutan pasar ekuitas seringkali dimengerti sebagai pasar saham dan sebutan saham sering dimaksudkan sebagai saham biasa (Tandelilin, 2010: 36).

Di antara surat-surat berharga yang diperdagangkan di pasar modal, saham biasa (common stock) merupakan salah satu jenis efek yang paling banyak diperdagang-kan di pasar modal. Bahkan saat ini dengan semakin banyaknya emiten yang mencatat-kan sahamnya di bursa efek, perdagangan saham semakin marak dan menarik para investor untuk terjun dalam jual beli saham. Jika perusahaan hanya mengeluarkan satu kelas saham saja, saham ini biasanya dalam bentuk saham biasa (common stock) (Jogiyanto, 2009).

Di antara emiten (perusahaan yang menerbitkan surat berharga), saham biasa juga merupakan yang paling banyak digunakan untuk menarik dana dari masyarakat. Secara sederhana, saham didefinisikan se-bagai tanda penyertaan atau pemilikan se-seorang atau badan dalam suatu perusa-haan. Saham biasa ada dua jenis, yaitu sa-ham atas nama dan saham atas unjuk. Un-tuk saham atas nama, nama pemilik saham tertera di atas saham tersebut, sedangkan saham atas unjuk yaitu nama pemilik saham tidak tertera di atas saham, tetapi pemilik saham adalah yang memegang saham ter-sebut. Seluruh hak-hak pemegang saham akan diberikan pada penyimpan saham tersebut. 
Anoraga dan Pakarti (2001) mende-finisikan saham sebagai surat berharga buk-ti penyertaan atau pemilikan individu mau-pun institusi dalam suatu perusahaan. Man-faat yang dapat diperoleh jika memiliki saham suatu perusahaan adalah.

1) Deviden, bagian dari keuntungan perusahaan yang dibagikan kepada pemilik saham.

2) Capital Gain adalah keuntungan yang diperoleh dari selisih jual dengan harga belinya.

3) Manfaat non finansial, yaitu timbulnya kebanggaan dan kekuasaan, memperoleh hak suara dalam menen-tukan jalannya perusahaan.

\section{Right Issue}

Right issue di Indonesia dikenal
dengan istilah Hak Memesan Efek Terlebih Dahulu (HMED). Right issue adalah pengeluaran saham baru dalam rangka pe-nambahan modal perusahaan, namun lebih dahulu ditawarkan kepada pemegang saham saat ini (existing holder). Dengan ka-ta lain pemegang saham lama mempunyai preemtive right atau hak memesan efek terlebih dahulu atas sahamsaham baru tersebut (Darmadji dan Fakhruddin, 2001).

Menurut Robert Ang (1997), right issue adalah hak yang diberikan kepada semua pemegang saham untuk membeli saham dengan harga yang telah ditentukan, biasanya harganya di bawah harga pasar. Right issue memberikan hak bagi pemegang saham lama untuk membeli terlebih dahulu (preemptive right) saham baru pada harga tertentu dalam waktu kurang dari 6 bulan (Samsul, 2006).

Alasan memilih right issue dibandingkan dengan penawaran biasa (Rejeki, 2006):

1) Biaya yang dikeluarkan lebih murah daripada penawaran umum karena tidak harus menggunakan penjamin (underwriter) yang akan menjamin bahwa saham yang ditawarkan akan laku semua.
2) Pemegang saham lama dapat mempertahankan proporsi kepemilikan sahamnya dengan cara menggunakan haknya untuk membeli right tersebut.

Saham bisa menjadi lebih likuid karena jumlahnya menjadi jauh lebih besar dan bisa meningkatkan frekuensi perdagangan. Dalam right issue setiap pemegang saham yang memiliki hak preemptive dapat membeli atau melepaskan saham yang di-milikinya setiap saat dan dengan harga ter-tentu tanpa harus meminta izin kepada pe-rusahaan/pemegang saham lainnya.

\section{METODE PENELITIAN Jenis Penelitian}

Sifat penelitian ini adalah deskriptif, yaitu penelitian yang memberikan gamba-ran dan mengungkapkan suatu masalah, keadaan, peristiwa sebagaimana adanya atau mengungkapkan fakta secara lebih mendalam. Pelaksanaan dan hasil penelitian deskriptif tidak terbatas pada pengumpulan dan penyusunan data serta penggambaran suatu objek penelitian tetapi meliputi analisis dan interpretasi data. Rancangan penelitian ini berupa studi kasus, di mana penelitian dilakukan terhadap suatu objek penelitian dalam waktu tertentu dengan me-nekankan pada kedalaman analisis untuk tujuan evaluasi bukan untuk pengujian hi-potesa. Sesuai dengan sifat penelitian des-kriptif pada penelitian ini tidak ada hipo-tesa.

\section{Metode Pengumpulan Data}

Data yang dibutuhkan dalam penelitian ini adalah data sekunder yang terdiri dari:

1) Laporan keuangan PT BW Plantation, Tbk. tahun 2014, diperoleh dari website perusahaan.

2) Laporan keuangan perusahaan industri pertambangan dan jasa pertambangan yang sudah go public, yang diperoleh dari masing-masing website. 
3) Data harga saham perusahaan industri pertambangan dan jasa pertambangan pada bulan Desember 2014.

4) Data mengenai tingkat suku bunga bebas risiko, dalam penelitian ini menggunakan suku bunga Bank Indonesia Desember 2014.

5) Data market risk premium yang diperoleh dari hasil penelitian yang dilakukan

olehwww.damodaran.com.

\section{Teknik Analisis Data}

Penelitian ini menggunakan dua pendekatan untuk menentukan nilai wajar ekuitas. Pertama, pendekatan pendapatan/ discounted cash flow (DCF) dengan free cash flow to equity model (FCFE). Pendekatan kedua yang digunakan adalah pendekatan pasar (relative valuation) dengan menggunakan price earning ratio (PER) price to book value (PBV) dan price to sales ratio $(\mathrm{P} / \mathrm{S})$.

\section{Discounted Cash Flow Valuation (DCF V)}

Data-data yang diperlukan dalam melakukan penelitian menggunakan metode DCF dengan free cash flow to equity model sebagai berikut.

1) Laporan keuangan tahunan dari perusahaan yang akan dinilai berupa neraca dan laporan laba rugi

2) Tingkat suku bunga bebas risiko, risk premium, dan beta perusahaan untuk mendapatkan tingkat diskonto.

3) Profil perusahaan dan prospek perusahaan ke depan.

4) Data tentang kondisi perekonomian Indonesia.

Untuk melakukan estimasi nilai wajar saham perusahaan dengan menggunakan metode discounted cash flow dengan free cash flow to equity model terlebih da-hulu harus ditentukan periode proyeksinya. Periode proyeksi dapat dikembangkan da-lam rentang waktu beberapa tahun, tetapi sebagian besar perusahaan menggunakan rentang waktu lima sampai sepuluh tahun (Brigham dan
Ehrhardt, 2005). Berda-sarkan Keputusan Kepala BAPEPAM-LK No. Kep-340BL/2009 paling kurang lima tahun. Menurut Prawoto (2004) investasi dapat diproyeksikan dengan menggunakan rentang waktu 4-10 tahun dan mengasumsikan terminal value pada akhir periode proyeksi.

\section{Estimasi Tingkat Pertumbuhan}

Untuk menentukan tingkat pertumbuhan $g$ digunakan rumus:

$$
g=\text { ROE x Retention Rate }
$$

Keterangan :

Retention rate $\quad=1-$ Dividend Payout Ratio atau persentase laba ditahan

ROE (return on equity) = laba bersih/total modal.

Retention rate adalah rasio antara laba ditahan dengan laba bersih yang telah disesuaikan. ROE (return on equity) adalah rasio laba bersih yang telah disesuaikan dengan nilai ekuitas dalam neraca.

\section{Cost of Equity}

Cost of equity merupakan tingkat pengembalian yang diharapkan oleh para investor terhadap dana yang mereka investasikan di perusahaan tersebut. Salah satu pendekatan yang banyak dipergunakan untuk melakukan estimasi cost of equity adalah dengan menggunakan CAPM (Capital Asset Pricing Model). (Damo-daran, 2006). Secara umum persamaan CAPM adalah sebagai berikut:

$$
\mathrm{K}_{\mathrm{e}}=\mathrm{R}_{\mathrm{f}}+\beta\left(\mathrm{R}_{\mathrm{m}}-\mathrm{R}_{\mathrm{f}}\right)
$$

Di mana $R_{\mathrm{f}}$ merupakan nilai risk-free rate, $\beta$ merupakan systematic risk dari ekuitas perusahaan di mana nilainya didapat dari hasil regresi return dari saham perusahaan tersebut terhadap market return, $\left(\mathrm{R}_{\mathrm{m}}-\mathrm{R}_{\mathrm{f}}\right)$ merupakan nilai expected equity risk premium.

Risk-free rate merupakan tingkat pengembalian bebas risiko atau tingkat pengembalian yang diketahui secara pasti oleh para investor. Menurut (Damodaran, 2006) yang dimaksud dengan investasi risk-free adalah tidak ada default risk, atau harus ada jaminan dari pemerintah, dii Indonesia referensi yang dapat digunakan adalah tingkat SBI. 
Nilai $\beta$ merupakan nilai yang didapatkan dari hasil regresi historis return saham perusahaan terhadap return market se-cara keseluruhan. Return market yang dapat dijadikan referensi di Indonesia adalah re-turn Indeks Harga Saham Gabungan (IH-SG). Nilai $\beta$ yang dipergunakan harus rele-van dengan industri yang akan dilakukan valuasi.

Expected equity risk premium meru-pakan nilai yang dapat diestimasi dengan menggunakan pendekatan country risk pre-mium. Alasan menggunakan country risk premium adalah masih terbatasnya data his-toris suatu negara. Secara umum persamaan untuk melakukan estimasi expected equity risk premium adalah (Damodaran, 2006):

Equity risk premium $=$ Base premium for mature equity market + Country premium.

\section{Free Cash Flow to Equity (FCFE)}

FCFE dihitung dengan mengurangi laba bersih dengan kebutuhan investasi dan menjumlahkan semua transaksi non kas seperti deperesiasi. Kemudian dikurangi modal kerja non kas dan ditambahkan de-ngan net kas masuk dari penerbitan hutang (Damodaran, 2002).

FCFE mengasumsikan bahwa semua free cash flow akan dibagikan ke pemilik modal seluruhnya sebagai deviden, sehingga tidak ada reinvestasi. Oleh karena itu, pertumbuhan FCFE akan sama dengan pertumbuhan laba bersih dan bukan pertumbuhan dari marketable securities.

Menurut Damodaran (2002) pertumbuhan suatu perusahaan biasa diperoleh dengan menghubungkan antara retention ratio yaitu porsi laba yang diinvestasikan kembali ke perusahaan, dengan return on equity (ROE). Namun, karena dalam perhi-tungan FCFE ini diasumsikan bahwa semua free cash flow akan dibagikan ke pemilik modal seluruhnya sebagai deviden, maka akan lebih tepat menggunakan istilah reinvestment rate dibandingkan dengan retention ratio (Novizantara 2011).
Menurut Prawoto (2004) perhitungan net cash flow to equity menggunakan rumus berikut:

$\mathrm{NCFE}=\mathrm{NIAT}+\mathrm{NCC}-\mathrm{CAPEX}-\mathrm{CNWC}+$ NCLTD.

Keterangan :

NIAT : Net Income after tax

NCC : Non Cash Charge

CAPEX : Capital Expenditure

CNWC : Change in net working capital

NCLTD : Net change in long term debt

Prawoto (2004) mengungkapkan me-mang ada variabel lain yang diartikan sebagai pendapatan ekonomis dari suatu perusahaan seperti net operating income (NOI) atau pre tax income, tetapi semua itu merupakan pendapatan yang kalau diambil akan berpengaruh pada jalannya kegiatan usaha perusahaan.

\section{Terminal Value}

Perhitungan terminal value menurut Damodaran (2002) didasarkan pada kenya-taan bahwa estimasi aliran kas tidak dapat dilakukan setiap tahun selamanya, sehingga biasanya dilakukan penutupan dalam peni-laian DCF dengan menghentikan estimasi cash flow pada suatu tahun ( tahun termi-nal/tahun akhir

$$
\text { PBV - market value per share }
$$

estimasi) untuk kemudian dilakukan penghitungan nilai terminal yang merefleksikan nilai perusahaan pada saat itu. Penggunaan terminal value dalam peni-laian ini dilandasi asumsi bahwa perusa-haan tersebut akan going concern dengan tingkat pertumbuhan cash flows yang kons-tan selamanya setelah tahun terminal (Da-modaran, 2002). Sementara menurut Mur-hadi (2009) rumus umum yang digunakan dalam terminal value sebagai berikut:

Terminal value $: \frac{F C F E_{n+1}}{K_{e, s t}-g_{n}}$

Keterangan

$\mathrm{FCFE}_{\mathrm{n}+1}$ : Arus kas bersih pada tahun $\mathrm{n}$

$\mathrm{K}_{\mathrm{e}, \mathrm{st}} \quad$ : Cost of equity periode stable growth

$\mathrm{g}_{\mathrm{n}} \quad$ : Tingkat pertumbuhan stabil 


\section{Penentuan Nilai Ekuitas}

Nilai dari ekuitas adalah penjumlahan dari nilai kini dari arus kas bersih perusahaan pada pertumbuhan tinggi ditambah dengan nilai kini terminal value pada pertumbuhan stabil. Rumus umum dalam menentukan nilai ekuitas dapat dirumuskan sebagai berikut:

$$
\begin{aligned}
& \text { Nilai ekuitas }= \\
& \sum_{t=1}^{t+n} \frac{F C F E_{t}}{\llbracket\left(1-k \rrbracket_{e n g}\right)^{t}}+\frac{\text { terminal value }}{\llbracket\left(1-k \eta_{e n g}\right)^{t}}
\end{aligned}
$$

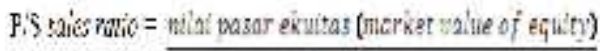

$$
\begin{aligned}
& \text { pendąarmi (verencues) } \\
& \begin{array}{ll} 
& \multicolumn{1}{c}{\text { Keterangan }} \\
\text { FCFE }_{\mathrm{t}} & : \text { free cash flow to equity } \\
\mathrm{n} & : \text { umur aset } \\
\mathrm{K}_{\mathrm{e}} & : \text { cost of equity }
\end{array}
\end{aligned}
$$

\section{Relative valuation}

Untuk memperoleh nilai dengan pendekatan data pasar, terlebih dahulu harus dilakukan pemilihan perusahaan yang seukuran dan sebanding dengan obyek yang akan dinilai. Metode pada pendekatan data pasar yang digunakan pada penelitian ini adalah metode relative valuation. Perusa-haan-perusahaan yang akan dibandingkan adalah perusahaan yang terdaftar di Bursa Efek Indonesia.

Metoda relative valuation atau pembanding perusahaan terbuka menggunakan rasio ukuran kinerja perusahaan publik pembanding sebagai faktor pengali (multiples) terhadap variabel keuangan fun-damental perusahaan yang dinilai. Berikut beberapa variabel yang sering digunakan sebagai multiples (Ruky, 1999).

\section{Pricelearning ratio}

Rasio antara harga saham per lembar de-ngan pendapatan per lembar. Multiple ini paling banyak digunakan. Nilai ekui-tas diperkirakan dengan melihat kemam-puan perusahaan dalam menghasilkan laba bersih per saham (Damodaran, 20-02):

$$
\mathrm{PLR}=\frac{\text { market price per share }}{\text { earning per share }}
$$

\section{Price/sales ratio}

Rasio antara nilai pasar ekuitas dibandingkan dengan penda- patannya (revenues). Nilai ekuitas diperkirakan dengan melihat kemampuan perusahaan dalam menghasilkan penjualan/penerimaan (Damodaran, 2002)

\section{Price/book value}

Rasio antara harga pasar saham per lem-bar dengan nilai buku ekuitas per lembar (Damodaran, 2002)

\section{Discount for Lack of Marketability}

Menurut Ruky (1999) discount adalah potongan yang diberikan kepada suatu indikasi nilai dari business interest atau saham yang berhasil diperkirakan. Pemberian diskon yang terkait dengan unsur kendali disebut minority interest discount. Pemberian diskon juga terkait dengan tingkat kesulitan saham tersebut untuk dikonversi secara cepat menjadi uang tunai, diskon jenis ini disebut discount for lack of marketability. Pratt dan Niculita (2008) berpendapat ada dua bentuk umum berda-sarkan studi empiris yang digunakan untuk mengkuantifikasikan diskon ini bagi $m i$ nority interest di perusahaan, yaitu diskon pada penjualan dari saham terbatas suatu perusahaan yang diperdagangkan secara umum dan diskon pada penjualan saham perusahaan tertutup dibandingkan dengan harga saham perusahaan yang sama yang melakukan penawaran pertama sahamnya secara berurutan.

Faktor marketability memberikan nilai tambah terhadap sekuritas. Pasar akan memberikan suatu premi terhadap likuiditas yang dimiliki oleh sekuritas sehingga saham dari perusahaan yang tertutup akan bernilai lebih kecil dibandingkan dengan nilai saham yang biasa diperdagangkan di pasar saham atau bursa efek (Prawoto, 2004).

Konsep marketability berkenaan dengan likuid-nya kepentingan, yaitu apakah bisa cepat dan pasti kepentingan itu 
bisa dikonversi ke dalam bentuk tunai. Oleh karena itu marketability didefinisikan seba-gai kemampuan untuk mengubah properti ke dalam uang tunai secepat mungkin de-ngan biaya administrasi dan transaksi yang minimal dan dengan tingkat kepastian me-realisasikan jumlah yang diharapkan secara netto (Prawoto, 2004). Berdasarkan peneli-tian besaran illikuidity discount adalah 20-30 persen dari estimasi nilai (Damodaran, 2002). Prawoto (2004) bahwa untuk illi-kuidity discount / discount for lack mar-ketability saham minoritas untuk perusaha-an tertutup lebih besar dibandingkan peru-sahaan saham terbatas perusahaan terbuka. Rata-rata diskon dan premi menurut hasil penelitian di Amerika Serikat besarnya sekitar 30 persen.

\section{Penetapan Rekonsiliasi Nilai}

Menurut (Prawoto 2004) proses rekonsiliasi nilai dilakukan dengan mempertimbangkan tujuan diadakan penelitian, mengkaji kembali apakah metoda penelitian yang digunakan sudah tepat, dan apa-kah indikasi nilai yang diperoleh itu telah rasional. Hasil rekonsiliasi nilai dilakukan dengan membuang indikasi nilai yang yang ekstrim (outliers). Data yang outliers bisa dipertimbangkan namun dengan memberi-kan bobot yang rendah. Langkah selan-jutnya dilakukan investigasi alasan me-ngapa terjadi angka yang outliers, direkon-siliasi dan kemudian dijelaskan anomali yang terjadi.

\section{ANALISIS DATA DAN PEMBA- HASAN}

\section{Estimasi Nilai Wajar Ekuitas}

\section{Discounted Cash Flow Valuation (CCFV)}

Dalam penelitian ini penulis menggunakan pendekatan pendapatan dengan metode discounted cash flow (DCF) dengan model free cash flow to equity (FCFE). Adapun data yang digunakan dalam pene-litian ini adalah laporan keuangan dan la-poran tahunan PT. BW Plantation, Tbk. tahun 2014 - 2015 dan informasi dari sum-ber-sumber yang dianggap relevan dalam penelitian ini. Berikut adalah tahapan hasil dari penelitian estimasi nilai wajar saham PT. BW Plantation, Tbk. pasca right issue pada tahun 2015.

Proyeksi laporan keuangan

Untuk melakukan estimasi nilai wa-jar ekuitas dengan metoda discounted cash flows terlebih dahulu harus ditentukan peri-ode proyeksinya. Periode proyeksi dapat dikembangkan dalam rentang waktu bebe-rapa tahun, tetapi sebagian besar perusa-haan menggunakan rentang waktu lima sampai sepuluh tahun (Brigham dan Ehrn-ardt, 2005), dan menurut keputusan BAPE-PAM-LK nomor: Kep-340-BL/2009 paling kurang lima tahun. Sementara menurut (Prawoto, 2004) investasi dapat diproyek-sikan dengan menggunakan rentang waktu 4-10 tahun periode proyeksi eksplisit.

Mengestimasi tingkat pertumbuhan.

Untuk menentukan tingkat pertumbuhan $(\mathrm{g})$ digunakan dengan menggunakan data historis dan kemudian dilakukan pembobotan sesuai dengan kewajaran. Berikut adalah hasil perhitungaannya dengan menghasilkan tingkat pertumbuhan 10,98 persen.

Tabel 1

Proyeksi Pendapatan PT. BW Plantation, Tbk. Per 31 Desember 2016 (Dalam Milyar Rupiah)

\begin{tabular}{|c|c|}
\hline Tahun & Pendapatan \\
\hline 2016 & 2.968 \\
\hline 2017 & 3.294 \\
\hline 2018 & 3.655 \\
\hline 2019 & 4.057 \\
\hline 2020 & 4.503 \\
\hline 2021 & 4.997 \\
\hline 2022 & 5.546 \\
\hline 2023 & 6.156 \\
\hline 2024 & 6.832 \\
\hline 2025 & 7.582 \\
\hline
\end{tabular}

Sumber: berbagai sumber, diolah, 2016

Berikutnya adalah menentukan rasio dari akun-akun laporan keuangan yang akan diproyeksi. Setiap akun-akun dipresentasikan terhadap pendapatan pada masing-masing tahun aktual. Dalam penelitian ini rasio rata-rata pada dua tahun terakhir yang dipilih yaitu tahun 2014 dan 
2015. Hal ini karena rasio tahun terakhir lebih mencerminkan kondisi perekonomian saat penilaian. Selanjutnya rasio tahun terakhir dikalikan dengan setiap penda-patan pada tahun proyeksi. Hasil perkalian tersebut menjadi nilai akun-akun laporan keuangan berupa neraca dan laporan laba rugi pada tahun proyeksi.

Cost of equity

Mengestimasi faktor diskonto atau cost of equity yang merupakan tingkat pengembalian yang disyaratkan oleh investor. Perhitungan cost of equity menggunakan metode capital asset pricing model (CA-PM). Berdasarkan metode CAPM tingkat pengembalian yang disyaratkan investor diperoleh dari tingkat suku bunga bebas re-siko ditambah dengan perkalian antara beta perusahaan dengan premi resiko.

Tabel 2

Perhitungan Beta PT. BW Plantation, Tbk. (Dalam Miliar Rp kecuali beta)

\begin{tabular}{|l|l|l|l|l|l|}
\hline No & $\begin{array}{l}\text { Perusahaan } \\
\text { Pembanding }\end{array}$ & Beta & Debt & Equity & D/E \\
\hline 1 & $\begin{array}{l}\text { PT Astra } \\
\text { Agro } \\
\text { Lestari Tbk. }\end{array}$ & 0,40 & 9.813 & 11.698 & 0,84 \\
\hline & $\begin{array}{l}\text { PT Bakrie } \\
\text { Sumatera } \\
\text { Plantations }\end{array}$ & 0,26 & 13.569 & 3.356 & 4,04 \\
\hline $\begin{array}{l}\text { PT Sinar } \\
\text { Mas Agro } \\
\text { Resources } \\
\text { ad } \\
\text { Technology } \\
\text { Tbk }\end{array}$ & $\begin{array}{l}\text { PT } \\
\text { Perusahaan } \\
\text { Perkebunan } \\
\text { London } \\
\text { Sumatra } \\
\text { Indonesia }\end{array}$ & 0,67 & 16.510 & 7.622 & 2,14 \\
\hline & Rata-rata & 0,32 & 10.307 & 7.503 & 1,81 \\
\hline & $\begin{array}{l}\text { PT. BW } \\
\text { Plantation, } \\
\text { Tbk. }\end{array}$ & 1,25 & 11.005 & 6.652 & 1,65 \\
\hline
\end{tabular}

Tabel 3

Perhitungan Unleverage Beta PT. BW Plantation, Tbk.

\begin{tabular}{|r|l|r|l|}
\hline No & & \multicolumn{2}{|c|}{ Keterangan } \\
\hline 1 & Rata - rata beta & 0,32 & \\
\hline 2 & Pajak & $25 \%$ & UU No. 36 tahun 2008 \\
\hline 3 & D/E rasio & 1,81 & Rata - rata D/E \\
\hline \multicolumn{2}{|l}{ Unleverage beta } & 0,14 & $\begin{array}{l}\text { Rata - rata beta / } \\
(1+(1-\mathrm{T}) \times(D / E \text { rasio })\end{array}$ \\
\hline
\end{tabular}

Tabel 4

Perhitungan Leverage Beta PT. BW Plantation, Tbk.

\begin{tabular}{|r|l|r|l|}
\hline No & & \multicolumn{2}{|c|}{ Keterangan } \\
\hline 1 & Unleverage beta & 0,14 & \\
\hline 2 & Pajak & $25 \%$ & UU No. 36 tahun 2008 \\
\hline 3 & D/E rasio perusahaan & 1,65 & Kewajiban / Ekuitas \\
\hline \multicolumn{2}{|l}{} \\
\multicolumn{2}{|l|}{ Leverage beta } & 0,31 & Unleverage beta X \\
(1+(1-T) $\times$ (D/E rasio perusahaan)
\end{tabular}
Tabel 5

Perhitungan Cost of Equity $\left(\mathrm{k}_{\mathrm{e}}\right)$ PT. BW Plantation, Tbk.

\begin{tabular}{|r|l|r|l|}
\hline No & Uraian & \multicolumn{2}{|c|}{ Keterangan } \\
\hline 1 & $\mathrm{Rf}$ & $6,00 \%$ & Obligasi Negara RI0146 \\
\hline 2 & $\mathrm{Rm}-\mathrm{Rf}$ & $9,65 \%$ & Aswath Damodaran \\
\hline 3 & Beta & 0,31 & Leverage Beta \\
\hline Cost Of Equity & $8,99 \%$ & Ke $=\mathrm{Rf}+\beta(\mathrm{Rm}-\mathrm{Rf})$ \\
\hline
\end{tabular}

Dalam penelitian ini perusahaan yang digunakan sebagai pembanding adalah PT Astra Agro Lestari Tbk., PT Bakrie Sumatera Plantations, PT Sinar Mas Agro Resources ad Technology Tbk dan PT Pe-rusahaan Perkebunan London Sumatra Indonesia. Perusahaan tersebut dipilih karena sama - sama bergerak di bidang indus-tri kelapa sawit dan skala usaha hampir sama. Nilai beta perusahaan pembanding didapat dari www.reuters.com.

\section{Free Cash Flow to Equity (FCFE)}

Dalam penentuan seberapa besar nilai FCFE ditentukan oleh nilai akunakun pada tahun proyeksi. Akun-akun tersebut antara lain adalah net income, depresiasi dan amortisasi, perubahan modal kerja, pengeluaran modal dan perubahan hutang jangka panjang. Setelah komponen-kom-ponen yang diperlukan dalam perhitungan arus kas bersih ke perusahaan diketahui, langkah selanjutnya adalah membuat perhi-tungan arus kas bersih ke ekuitas atau FCFE seperti tertera di bawah ini:

Tabel 6

Perhitungan FCFE PT. BW Plantation, Tbk. (Dalam Miliar Rupiah) 


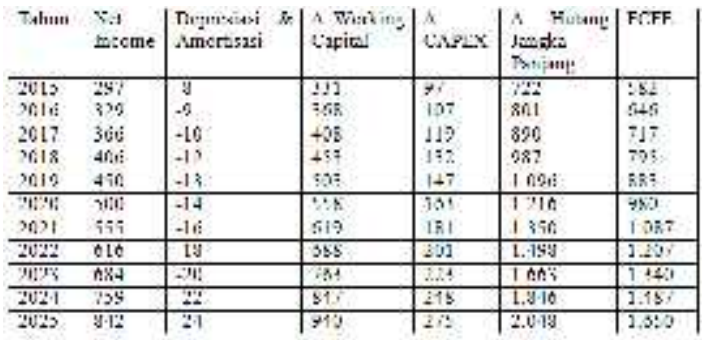

$\mathrm{FCFE}=\mathrm{NIAT}+\mathrm{NCC}-\mathrm{CAPEX}-\mathrm{CNWC}+$ NCLTD.

\section{Terminal value}

Dengan asumsi bahwa perusahaan akan terus beroperasi (going concern), maka proyeksi terhadap laporan keuangan dibatasi oleh dua kondisi. Kondisi pertama merupakan kondisi di mana perusahaan akan tumbuh tinggi setelah itu memasuki kondisi kedua dengan pertumbuhan stabil. Pertumbuhan yang stabil ini menjadi acuan penetapan terminal value dari nilai ekuitas.

Tabel 7

Perhitungan Terminal Value PT. BW Plantation, Tbk.

(Dalam Milyar Rupiah)

\begin{tabular}{|r|r|r|r|r|r|}
\hline No & \multicolumn{5}{|c|}{ Uraian } \\
\hline & Constant Growth & FCFE 5 & FCFE $n+1$ & Ke & Terminal Value \\
\hline 1. & $4 \%$ & 1.650 & 1.716 & $8,89 \%$ & 35.094 \\
\hline
\end{tabular}

Estimasi nilai wajar ekuitas

Di dalam konsep pendekatan pendapa-tan/discounted cash flow dengan free cash flow to equity model, estimasi nilai wajar ekuitas merupakan penjumlahan dari nilai kini equity dan terminal value. Dari perhitungan tersebut diperoleh estimasi nilai wajar ekuitas PT. BW Plantations Tbk. sebesar Rp1.055. Berikut perhitungan nilai ekuitas per lembar saham PT. BW Plantation, Tbk

Tabel 8

Perhitungan Nilai Ekuitas PT. BW Plantation, Tbk.

\begin{tabular}{|c|c|c|c|c|}
\hline $\mathrm{N}: \mathrm{O}$ & Uniani & lamulith & niek:mlis & Pilai S: kill n"r. \\
\hline 1 & FCFF1 & $545.059,050.39$ & 0, $9183455: 1$ & 593.314 .583 .757 \\
\hline & FCFE 2 & 717.027084 .184 & 0.24335558 & 604.713 .457 .493 \\
\hline & rete? & $795.9 y .536 .380$ & 0,77454731 & $615.243,455.104$ \\
\hline & rert 4 & 391.215 .118 .175 & $0,711253: 54$ & 629.100 .900 .718 \\
\hline & rerts & 092.211 .312 .120 & 0,653175871 & 640.255 .052 .321 \\
\hline j & rett 6 & 1.093 .005 .456 .002 & 0,59934212 & 652.573 .335 .455 \\
\hline 2 & rerez & 1.207 .410 .796 .574 & $0,5500521: 4$ & 665.117 .132 .713 \\
\hline & reres & $1,210,012.211,261$ & 0,505032255 & $672,902,152,51]$ \\
\hline 9 & FCFES & $1 / 137,237,311,381$ & 0,101521273 & 690,932,33:,777 \\
\hline 10 & $+C+t=10$ & 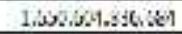 & $0,120670.25$ & (4)1,21.1.135,3i5 \\
\hline \multicolumn{4}{|c|}{ Jumlah pvitct: $\{a j$} & 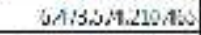 \\
\hline \multicolumn{4}{|c|}{ Ieminalvalue it! } & $3 \mathrm{~J}, 041,3,1,330,9,8$ \\
\hline \multicolumn{4}{|c|}{ 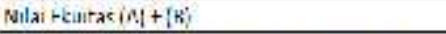 } & 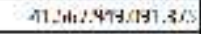 \\
\hline \multicolumn{4}{|c|}{ 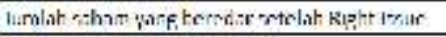 } & 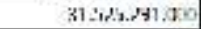 \\
\hline \multicolumn{4}{|c|}{ 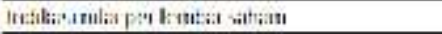 } & 1517 \\
\hline \multicolumn{3}{|c|}{ 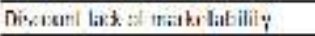 } & $10 \%$ & 112 \\
\hline \multirow{2}{*}{\multicolumn{3}{|c|}{ 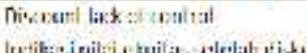 }} & $10 \%$ & 137 \\
\hline & & & 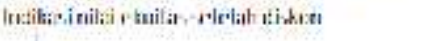 & $105: 5$ \\
\hline
\end{tabular}

\section{Relative Valuation}

Langkah awal menggunakan pendekatan relative valuation adalah menentukan perusahaan pembandingyang me-miliki karakteristik yang sama dengan peru-sahaan yang dinilai. Karakteristik yang sa-ma antara lain perusahaan berada pada kla-sifikasi industri properti dan sama-sama dimiliki oleh pemerintah sebagai pe-megang saham mayoritas. Untuk menen-tukan nilai saham menggunakan pende-katan relative valuation didasari dengan multiple yang relevan dari perusahaan pembanding. Multiple yang digunakan da-lam penelitian ini adalah price earning ratio (PER), price to book value (PBV), dan Price to sales ratio $(\mathrm{P} / \mathrm{S})$ dari perusahaan pembanding.

\section{Price Earning Ratio}

Price Earning Ratio adalah rasio dengan membandingkan antara harga per lembar saham dengan pendapatan per lembar saham. Tabel berikut menunjukkan per-hitungan Price Earning Ratio (PER) dari perusahaan pembanding.

Tabel 9

Perhitungan Price Earning Ratio (PER)

\begin{tabular}{|c|l|c|}
\hline No & \multicolumn{1}{|c|}{ Perusahaan } & PER \\
\hline 1 & PT. Astra Agro Lestari & 40,32 \\
\hline 2 & $\begin{array}{l}\text { PT. Bakrie Sumatera } \\
\text { Plantations }\end{array}$ & 0,66 \\
\hline 3 & $\begin{array}{l}\text { PT. Sinar Mas Agro } \\
\text { Resources \& Technology }\end{array}$ & 12,90 \\
\hline 4 & $\begin{array}{l}\text { PT. Perusahaan Perkebunan } \\
\text { London Sumatera Indonesia }\end{array}$ & 14,38 \\
\hline
\end{tabular}




\section{Rata-rata}

17,07

\section{Price to book value}

Price to book value adalah rasio dengan membandingkan antara harga pasar per lembar saham dengan nilai buku ekuitas per lembar saham. Tabel berikut adalah per-hitungan price to book value (PBV) dari perusahaan pembanding.

Tabel 10

Perhitungan Price to Book Value (PBV)

\begin{tabular}{|c|l|c|}
\hline No & \multicolumn{1}{|c|}{ Perusahaan } & PBV \\
\hline 1 & PT. Astra Agro Lestari & 1,32 \\
\hline 2 & PT. Bakrie Sumatera Plantations & 0,23 \\
\hline 3 & $\begin{array}{l}\text { PT. Sinar Mas Agro Resources \& } \\
\text { Technology }\end{array}$ & 1,66 \\
\hline 4 & $\begin{array}{l}\text { PT. Perusahaan Perkebunan London } \\
\text { Sumatera Indonesia }\end{array}$ & 1,26 \\
\hline \multicolumn{2}{|c|}{ Rata-rata } & 1,12 \\
\hline
\end{tabular}

\section{Price to sales ratio}

Price to sales ratio adalah rasio mu-ltiple dengan membandingkan antara harga pasar dari ekuitas dan pendapatan yang diperoleh. Berikut adalah perhitungan price to sales ratio $(\mathrm{P} / \mathrm{S})$ dari perusahaan yang dijadikan sebagai pembanding dalam pene-litian ini.

Tabel 11

Perhitungan Price to Sales Ratio (P/S)

\begin{tabular}{|l|l|l|}
\hline No & \multicolumn{1}{|c|}{ Perusahaan } & P/S \\
\hline 1 & PT. Astra Agro Lestari & 1,91 \\
\hline 2 & PT. Bakrie Sumatera Plantations & 0,33 \\
\hline 3 & $\begin{array}{l}\text { PT. Sinar Mas Agro Resources \& } \\
\text { Technology }\end{array}$ & 0,33 \\
\hline 4 & $\begin{array}{l}\text { PT. Perusahaan Perkebunan London } \\
\text { Sumatera Indonesia }\end{array}$ & 2,1 \\
\hline \multicolumn{2}{|c|}{ Rata-rata } & 1,18 \\
\hline
\end{tabular}

Nilai ekuitas dari tiga multiple di atas selanjutnya dikalikan dengan discuont for lack of marketability (DLOM) sebesar 10 persen dan discuont for lack of control, kemudian hasilnya dijadikan rata-rata untuk mendapat estimasi nilai per lembar saham. Tabel 12 menunjukkan nilai per lembar saham dengan pendekatan relative valuation

Tabel 12

Nilai Per Lembar Saham Dengan Pendekatan Relative Valuation

\begin{tabular}{|c|c|c|c|c|c|c|}
\hline No & Uraian & Pengali & EPS & BVS & RPS & Jumlah \\
\hline 1 & PER & 17,07 & 9,43 & & & 161 \\
\hline & PBV & 1,12 & & 211 & & 236 \\
\hline & $\mathrm{P} / \mathrm{S}$ & 1,18 & & & 85,00 & 100 \\
\hline \multicolumn{6}{|c|}{ Rata - rata } & 166 \\
\hline \multicolumn{5}{|c|}{ DLOC } & $10 \%$ & 17 \\
\hline \multicolumn{5}{|c|}{ DLOM } & $10 \%$ & 17 \\
\hline \multicolumn{6}{|c|}{ Indikasi nilai per lembar saham } & 133 \\
\hline
\end{tabular}

\section{Rekonsiliasi Nilai}

Hasil penilaian dengan menggunakan kedua pendekatan tersebut menghasilkan indikasi nilai yang berbeda. Penilaian menggunakan metode discounted $\mathrm{ca}$ sh flow dengan free cash flow to equity model memberikan indikasi nilai per lembar saham PT. BW Plantation, Tbk. sebesar Rp1.055, sementara penilaian yang dilaku-kan dengan metoda relative valuation menghasilkan indikasi nilai yaitu sebesar Rp133.

Tabel 13

Hasil Rekonsiliasi Nilai PT. BW Plantation, Tbk.

\begin{tabular}{|l|l|r|r|r|}
\hline No & Metode/model & Indikasi Nilai & Bobot & Nilai Tertimbang \\
\hline I & Discounted Cash Flow Method & & & \\
\hline 1 & Free Cash Flow to Equity Model & 1.055 & & \\
\hline & Jumlah (A) & 1.055 & $25 \%$ & \\
\hline II & Relative Valuation & & & \\
\hline 1 & Price Earning Ratio (PER) & 129 & & \\
\hline 2 & Price to Book Value (PBV) & 189 & & \\
\hline 3 Price to Sales Ratio (P/S) & 80 & & \\
\hline & Rata - Rata (B) & 133 & $75 \%$ & 99 \\
\hline & Jumlah (A+B) & & $100 \%$ & 363 \\
\hline Estimasi nilai wajar per lembar saham & & & 363 \\
\hline Range nilai penetapan saham & 336 & & 390 \\
\hline
\end{tabular}

Rekonsiliasi di atas menghasilkan estimasi nilai wajar per lembar saham sebesar Rp363 atau pada kisaran Rp336 Rp390. Estimasi nilai tersebut dapat dipergunakan oleh manajemen PT BW Plantations sebagai acuan untuk menentukan nilai wajar per lembar saham yang ditawarkan ke publik melalui right issue.

\section{KESIMPULAN, IMPLIKASI, SA- RAN, DAN BATASAN}

Berdasarkan analisis yang telah dilakukan pada bab sebelumnya, maka hasil yang dapat disimpulkan dari penelitian ini sebagai berikut. Indikasi nilai wajar per lembar saham PT. BW Plantation, Tbk. dengan menggunakan metoda DCF sebesar Rp1.055, sementara indikasi nilai wajar per lembar saham dengan metoda relative valuation sebesar Rp133, yaitu dengan menggunakan PER 
sebesar Rp129, PBV sebesar Rp189, dan $\mathrm{P} / \mathrm{S}$ sebesar Rp80. Hasil rekonsiliasi dari kedua metoda tersebut menghasilkan estimasi nilai wajar per lembar saham sebesar Rp363, atau pada kisaran antara Rp336 sampai dengan Rp390.

Harga penawaran saham yang ditetapkan pihak manajemen PT. BW Plantation, Tbk. pada saat Right Issue sebesar Rp400, sementara estimasi nilai wajar per lembar saham sebesar Rp363. Dengan demikian harga saham yang ditetapkan PT. BW Plantation, Tbk. dalam rangka right is-sue adalah overvalued.

Berdasarkan kesimpulan tersebut, saran yang dapat diberikan sebagai berikut. Bagi perusahaan. Estimasi nilai wajar lembar saham PT. BW Plantation, Tbk. sebesar Rp363 atau pada kisaran antara Rp336 sampai dengan Rp390 dapat digunakan se-bagai nilai pembanding harga pada saat right issue. Di samping itu manajemen perseroan harus memperhatikan waktu yang tepat dalam melaksanakan right issue, agar memperoleh dana sesuai dengan yang diharapkan.

Bagi investor. Nilai wajar per lem-bar saham PT. BW Plantation, Tbk. dapat dijadikan acuan dalam mengambil keputu-san menjual saham, karena harga saham yang overvalued cenderung untuk turun pa-da masa mendatang, maka akan lebih me-nguntungkan untuk memjual saham ter-sebut.

\section{DAFTAR PUSTAKA}

Ang, Robert. (1997). Buku Pintar Pasar Modal Indonesia. Jakarta: Mediasoft Indonesia.

Anoraga, Pandji dan Pakarti, Piji. (2001). "Pengantar Pasar Modal". Jakarta: Rineke Cipta

Brigham, Eugene F, and Houston, Joel F. (2001). Manajemen Keuangan Edisi Kedelapan. Jakarta: Erlangga
Brigham, Eugene F, and Ehrhardt, Michael C. (2005). Financial Management: Theory and Practice, $11^{\text {th }}$ edition, International Student Edition., Ohio: Thomson Learnin

Damodaran, Aswath. (2002). Investment Valuation. New York: John Willey \& Son, Inc

Damodaran, Aswath. (2006). Damodaran on Valuation. Swiss: John Wiley and Sains Inc

Darmadji, Tjiptono dan Fakhruddin, Hendy. (2001). Pasar Modal di Indonesia, Edisi 1. Jakarta : Salemba Empat.

Hidayati, Wahyu dan Harjanto, Budi. (2003). Penilaian Properti, Edisi Pertama. Yogyakarta, BPFE.

Husnan,S. (2001). Dasar-Dasar Manajemen Keangan, UPP AMP YKPN, Yogyakarta.

Husnan, Suad. (2003). Dasar-Dasar Teori Portofolio dan Analisis Sekuritas, Edisi ke-tiga. Yogyakarta: UPP AMP YKPN.

Jogiyanto. (2009). Teori Portofolio dan Analisis Investasi, Edisi Keenam. Yogyakarta: BPFE.

Laporan tahunan PT. BW Plantation Tbk 2013

Murhadi, Warner R. (2009). Analisis Saham Pendekatan Fundamental. Jakarta: PT. Indeks

Novizantara, Alfianur. (2008). "Pendekatan DCF Dan Relative Valuation Untuk Mengestimasi Nilai Wajar Saham PT Garuda Indonesia (Persero) Dalam Rangka IPO”, Tesis $S$-2. Program Studi MEP UGM, Program Pascasarjana, UGM, Yogyakarta (tidak dipublikasikan).

Prawoto, Agus. (2004). Penilaian Usaha, Edisi Pertama. Yogyakarta: BPFE 
Pratt P. Shannon. and Niculita V.Alina. (2008). "Valuing a Bussines: The Analysis and Appraisal of Closely Held

Companies", Fifth Edition. New York:

McGraw-Hill Companies Inc

Rejeki, Indah Sri. (2006). Kinerja Saham Setelah Seasoned Equity Offerings: Benarkah Underperformance?, Skripsi. FE UNS.

Rezaee, Zabihollah. (2001). Financial Institutions, Valuations, Mergers and Acquistions: The Fair Value Approach, $2^{\text {nd }}$ $E d$., New York: John Wiley \& Sons,Inc.

Riyanto, Bambang. (1996). Dasar-Dasar Pembelanjaan Perusahaan, Edisi

Keempat. Yogyakarta: BPFE.
Ruky, M, Saiful. (1999). "Menilai Penyertaan Dalam Perusahaan". Jakarta: Gramedia Pustaka Utama

Samsul, Mohamad. (2006). Pasar Modal dan Manajemen Portofolio. Jakarta: Erlangga

Standar Penilaian Indonesia tahun 2013

Tandelilin, Eduardus. (2010). Portofolio dan Investasi:Teori dan Aplikasi, edisi per-tama. Yogyakarta: Kanisius. 